\title{
Molecular and clinical studies in 107 Noonan syndrome affected individuals with PTPN11 mutations
}

Jeevana Praharsha Athota ${ }^{1}$, Meenakshi Bhat ${ }^{1,2}$, Sheela Nampoothiri ${ }^{3}$, Kalpana Gowrishankar ${ }^{4}$, Sanjeeva Ghanti Narayanachar ${ }^{2}$, Vinuth Puttamallesh', Mohammed Oomer Farooque ${ }^{1}$ and Swathi Shetty ${ }^{1 *}$ (D)

\begin{abstract}
Background: Noonan syndrome (NS), an autosomal dominant developmental genetic disorder, is caused by germline mutations in genes associated with the RAS / mitogen-activated protein kinase (MAPK) pathway. In several studies PTPN11 is one of the genes with a significant number of pathogenic variants in NS-affected patients. Therefore, clinically diagnosed NS individuals are initially tested for pathogenic variants in PTPN11 gene to confirm the relationship before studying genotype-phenotype correlation.

Methods: Individuals (363) with clinically diagnosed NS from four hospitals in South India were recruited and the exons of PTPN11 gene were sequenced.

Results: Thirty-two previously described pathogenic variants in eight different exons in PTPN11 gene were detected in 107 patients, of whom 10 were familial cases. Exons 3, 8 and 13 had the highest number of pathogenic variants. The most commonly identified pathogenic variants in this series were in exon 8 (c.922A > G, c.923A > G), observed in 22 of the affected. Congenital cardiac anomalies were present in 84\% of the mutation-positive cohort, the majority being defects in the right side of the heart. The most common facial features were downward-slanting palpebral fissures, hypertelorism and low-set posteriorly rotated ears. Other clinical features included short stature (40\%), pectus excavatum (54\%) and, in males, unilateral or bilateral cryptorchidism (44\%).

Conclusion: The clinical features and mutational spectrum observed in our cohort are similar to those reported in other large studies done worldwide. This is the largest case series of NS-affected individuals with PTPN11 mutations described till date from India.
\end{abstract}

Keywords: Noonan syndrome, PTPN11, Mutational analysis, Congenital heart defects, SHP-2, RASopathy

\footnotetext{
* Correspondence: swathi@chg.res.in

${ }^{1}$ Molecular Genetics, Centre for Human Genetics, Bengaluru 560100, India

Full list of author information is available at the end of the article
}

(C) The Author(s). 2020 Open Access This article is licensed under a Creative Commons Attribution 4.0 International License, which permits use, sharing, adaptation, distribution and reproduction in any medium or format, as long as you give appropriate credit to the original author(s) and the source, provide a link to the Creative Commons licence, and indicate if changes were made. The images or other third party material in this article are included in the article's Creative Commons licence, unless indicated otherwise in a credit line to the material. If material is not included in the article's Creative Commons licence and your intended use is not permitted by statutory regulation or exceeds the permitted use, you will need to obtain permission directly from the copyright holder. To view a copy of this licence, visit http://creativecommons.org/licenses/by/4.0/. The Creative Commons Public Domain Dedication waiver (http://creativecommons.org/publicdomain/zero/1.0/) applies to the data made available in this article, unless otherwise stated in a credit line to the data. 


\section{Background}

Worldwide a number of molecular studies have shown involvement of PTPN11 in causation of Noonan syndrome (NS). Our cohort of 363 patients from South India is one of the largest series described. The only other study on Indian patients with NS was published in 2017 by Phadke et al. [1], who screened 17 patients for PTPN11 and found pathogenic variants in 11 patients.

RASopathies are a well-documented group of autosomal-dominant disorders that result from mutations in genes in the RAS / mitogen-activated protein kinase (MAPK) pathway. Thirty genes have so far been implicated in the six different syndromes that are grouped as RASopathies [2, 3]. These syndromes are clinically heterogeneous, with overlapping features that complicate diagnosis without genetic testing. NS [MIM 163950] is the most common RASopathy, with a prevalence rate in livebirths of 1:1000 to 1:2500 [4]. It is postulated that a proportion of NS patients may be underdiagnosed owing to milder expression of the syndrome [5].

NS was first categorized as a separate entity in 1968 [6], with distinctive clinical features including facial dysmorphology, short stature and cardiac abnormalities [7, 8] (mainly pulmonary stenosis and patent ductus arteriosus). Numerous studies since then have shown that NS varyingly encompasses other features of skeletal, neurological, endocrine, haematological and cutaneous abnormalities [9]. Clinical features such as pulmonary stenosis (PS), short stature and thoracic deformities are more consistently associated with PTPN11 mutations than other clinical features [10-14]. The association of congenital heart defects in some studies is greater than $80 \%[1,10,11,13-30]$ indicating that NS is the second syndrome after Down syndrome with respect to frequency of cardiac defects.

Features of facial dysmorphism in NS include curly/ coarse/sparse hair, hypertelorism, downward slanting palpebral fissures, ptosis, strabismus, broad flat nose, high arched palate, micrognathia, short webbed neck and low-set posteriorly rotated ears, some of which are less distinguishable with age [31, 32]. Widely spaced and/or low-set nipples, pectus excavatum, pectus carinatum, scoliosis, cryptorchidism (in males), menorrhagia (in females), and neurocutaneous markers such as lentigines and café au lait spots are some of the other associated features. One of the studies reported pragmatic language impairment [PLI] in children with NS. People with PLI have difficulties in understanding and adapting to the needs of their conversational partners [33].

NS is also detectable prenatally by the presence of cystic hygromas, pleural effusions, polyhydramnios (33\%) with or without hydrops foetalis, congenital heart disease, chorioangiomas and other ultrasonographic markers [34]. A diagnosis of NS should be considered in a foetus observed to have significantly increased nuchal translucency with normal chromosomes [13, 34].

Fourteen different genes (PTPN11, KRAS, SOS1, RAF1, NRAS, BRAF, SHOC2, CBL, RRAS, RIT1, LZTR1, SOS2, MEK1 and PPPICB) [35-48] have thus far been implicated in aetiology of NS. Of these, the most commonly mutated gene in NS is PTPN11, with mutation frequency ranging between 22 and $100 \%$ $[10,20,23]$ across studies. PTPN11 codes for a ubiquitous non-receptor tyrosine phosphatase, the $\mathrm{Src}$ homology region 2 (SH2) domain-containing tyrosine phosphatase 2 or SHP2 protein. The structure and function of this protein, a member of the RAS/MAPK cascade, are highly conserved from invertebrates to mammals $[49,50]$. In humans, PTPN11 comprises 16 exons, with exon 1 consisting of an untranslated $5^{\prime}$ region and the translation initiation codon ATG, and exons 15 and 16 containing the stop codon TGA and $3^{\prime}$ untranslated region respectively (see Fig. 1). PTPN11 translates into a 593 amino acid protein comprising four distinct domains, two tandem $\mathrm{SH} 2$ domains (N-terminal $\mathrm{SH} 2$ and C-terminal $\mathrm{SH} 2$ ), a central PTP domain, and a C-terminal hydrophilic tail [51]. The SH2 domains are responsible for the interaction with phosphotyrosine-containing activators which contain binding sites for the N-SH2 domain. The PTP domain includes four loops, namely the P loop, pY loop, WPD loop and Q loop, which together enclose the 'active site pocket' and have specific roles in SHP2 activity. The residues $\mathrm{C} 459\left(\mathrm{X}_{5}\right)$ and $\mathrm{R} 465$ are important for catalysis. Stabilization of the phosphotyrosine substrate and enzyme complex is brought about by the R465 residue while $\mathrm{C} 459$ is responsible for a nucleophilic attack on the phosphorus atom leading to a transfer of the phosphate group from the substrate to the enzyme.

In the basic state there exists a low-level interaction between N-SH2 and the catalytic site of the PTP domain, maintaining an auto-inhibitory closed conformation. To be catalytically activated, this closed conformation has to be 'broken', allowing an 'open' configuration and entry of the substrate into the catalytic site. The open conformation is brought on by specific interactions between sites on the N-SH2 domain and upstream-signalling molecules. The conformational change thereby functions as a molecular switch turned on only upon interaction with signalling partners $[49,52]$. This ability allows the protein to function as a Ras/MAPK extracellular-regulated kinases $1 / 2($ ERK1/2) cascade stimulator on interaction with various activating molecules or agonists [53]. 


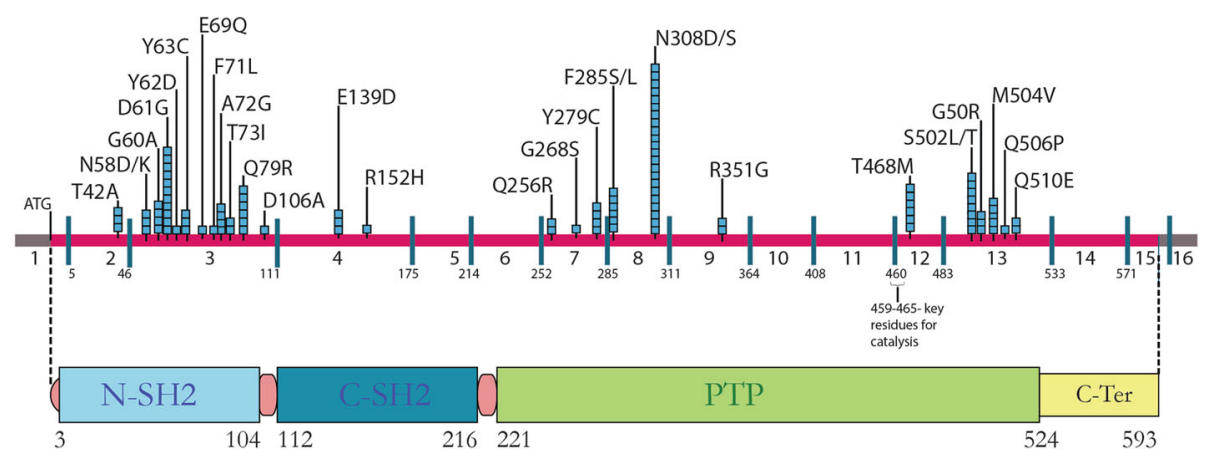

Fig. 1 Location of PTPN11 pathogenic variants shown along with exons and SHP-2 functional protein domains. The bar at top depicts the exons of the PTPN11 gene, with the coding region in pink. The blue boxes above the bar represent the number of patients observed with that particular pathogenic variant. The corresponding functional domains of the SHP-2 protein are shown below and includes the two SH2 domains and the protein tyrosine phosphatase (PTP) domain

The Ras/MAPK pathway is involved in cell proliferation, differentiation, metabolism, apoptosis and cell survival. The pathway is a cascade, controlled by the expression of various genes in a delicate balance, and a molecular aberration in any one of these deregulates the pathway causing multiple developmental anomalies $[2,50,54,55]$.

NS and Noonan syndrome with multiple lentigines (NSML, MIM "151100) are the result of a gain-offunction mutation in PTPN11 [52]. Conversely, lossof-function mutations have also been identified, which cause a skeletal disorder called metachondromatosis (MC; MIM\#156250).

We report here findings of our study of 363 patients clinically diagnosed as having Noonan or Noonan-like syndromes.

\section{Methods}

Clinical

We used a cohort of 363 patients from four hospitals in South India identified as NS patients by clinical geneticists using the van der Burgt scoring system [31]. A detailed pro forma record including three-generation pedigree, prenatal ultrasonographic findings, anthropometry and clinical features was prepared for each family. Venous blood samples were collected for DNA testing after informed assent/consent from the affected individuals and parents. Clinical photographs were taken where families had consented.

The characteristic features used in diagnosis included curly coarse hair, broad forehead, hypertelorism, downward slanting palpebral fissures, unilateral or bilateral ptosis, and low-set posteriorly rotated

Table 1 Clinical features in PTPN11 pathogenic variant positive patients in the present study

\begin{tabular}{llll}
\hline Craniofacial characteristics & $\begin{array}{l}\text { Percentage of PTPN11 positive } \\
\text { patients }\end{array}$ & Cardiac defects & $\begin{array}{l}\text { Percentage of PTPN11 positive } \\
\text { patients }\end{array}$ \\
Broad/High forehead & 31.7 & $\begin{array}{l}\text { Hypertrophic } \\
\text { cardiomyopathy }\end{array}$ & 8.5 \\
Hypertelorism & 50 & Atrial septal defect & 35.3 \\
Ptosis & 54.8 & Ventricular septal defect & 4.8 \\
$\begin{array}{l}\text { Downward Slanting palpebral } \\
\text { fissures }\end{array}$ & 84 & Pulmonary stenosis & 35.3 \\
Low set ears & 67 & Skin/Hair Abnormalities & Percentage of PTPN11 positive \\
Systemic Characteristics & Percentage of PTPN11 positive & patients \\
phort Stature & 40 & Dry Skin & 4.8 \\
$\begin{array}{l}\text { Webbed Neck/Low Posterior } \\
\text { Hairline }\end{array}$ & 60.9 & Curly hair/woolly hair & 8.5 \\
Pectus abnormalities & 53.6 & Café au lait patches & 9.75 \\
Widely spaced nipples & 34.14 & & \\
Cubitus Valgus & 12.19 & & \\
Cryptorchidism & 43.75 & & \\
\hline
\end{tabular}


ears. Other clinical features recorded were neck webbing, widely spaced nipples, pectus excavatum or pectus carinatum, cryptorchidism (in males) and neurocutaneous markers.

\section{Molecular studies}

DNA was isolated from peripheral blood samples. Three hundred and sixty-three samples which met the required clinical criteria of NS were processed. The DNA was used to amplify exons 2-16 of the PTPN11 gene by PCR amplification see (Additional file 1). The amplified products were purified, Sanger sequenced (Applied Biosystems ABI 3500), and analysed using Sequencher software ${ }^{\bullet}$.

\section{Analysis}

All the PTPN11 variants observed have been verified as reported pathogenic variants in HGMD (Human Gene Mutation Database) and also cross-verified with the NCBI database.

\section{Results}

Exon sequencing of PTPN11 gene revealed that 107 of the 363 (29\%) patients harboured a heterozygous pathogenic variant (Fig. 1). Clinical features of these individuals are described in Table 1. Age at diagnosis ranged between 28 days and 32 years (Fig. 2), and $61 \%$ of patients were males and 39\% females. A predilection for males among patients brought for medical evaluation earlier and more frequently is the norm in most Indian situations and this may account for the sex discrepancy in our cohort.

In 10 families, one parent was found to be clinically affected.

We identified a total of 32 different PTPN11 variants in 107 patients (Table 2), all of which have been reported earlier as pathogenic. As in earlier studies, exons 3 and 8 harboured the highest number of pathogenic variants (Fig. 1). The change c.922A > G (p.Asn308Asp) was the most common pathogenic variant observed in our patient set (11.21\%); the frequency of protein variants at residue 308 increases to $21 \%$ if the change
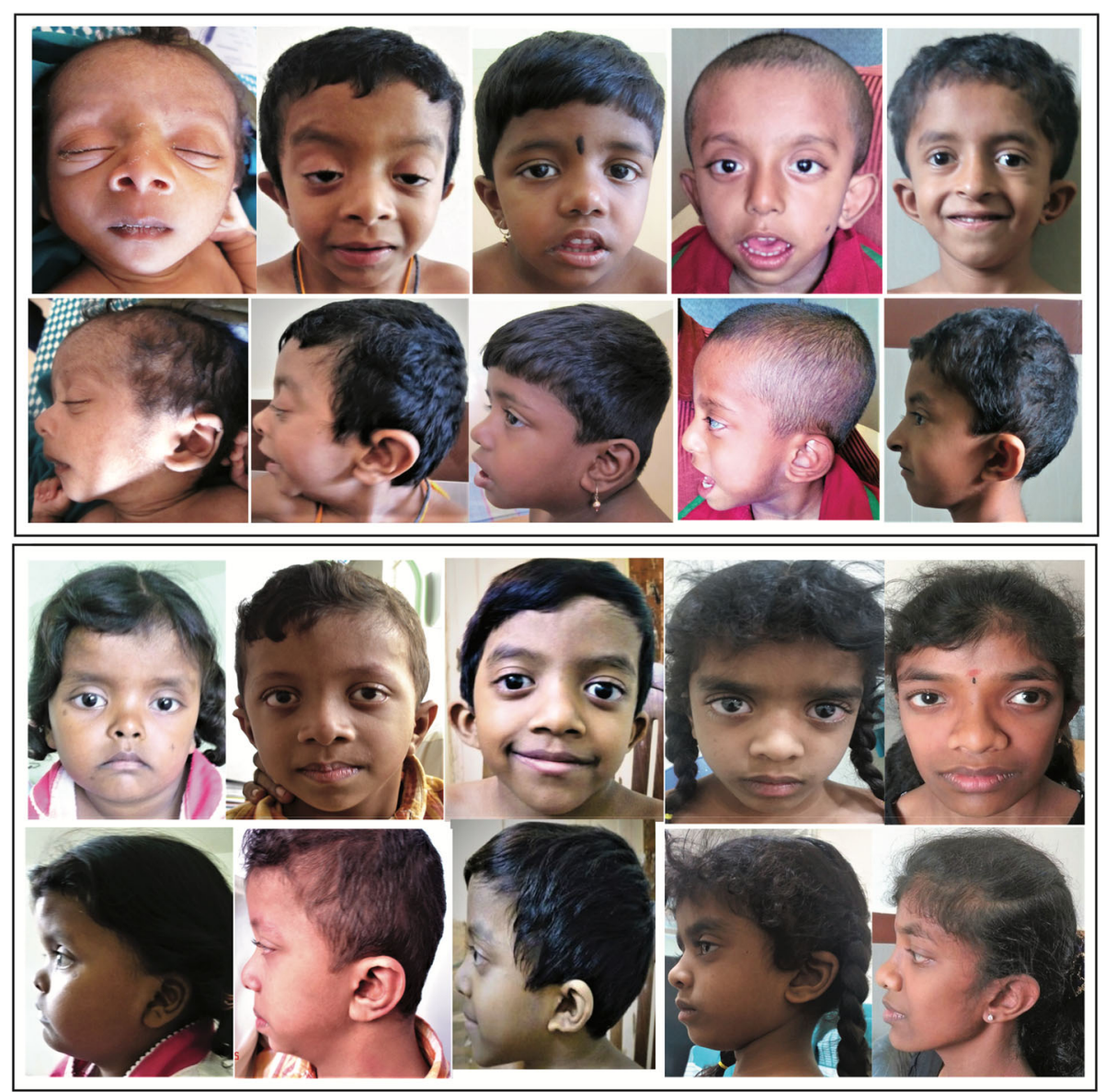

Fig. 2 Typical facial features (face front and side) in PTPN11 pathogenic variant positive NS patients. Curly/sparse hair, hooded eyes / ptosis, down-slanting palpebral fissures, hypertelorism and low-set, posteriorly rotated ears seen at ages ranging from 3 months to 16years 
Table 2 PTPN11 pathogenic variants ${ }^{\mathrm{a}}$ and their numbers observed in our study

\begin{tabular}{|c|c|c|c|c|}
\hline Exon number & Positive sample number & Variation seen & Number of times observed & Amino acid change \\
\hline Exon 2 & 3 & c. $124 \mathrm{~A}>\mathrm{G}$ & 3 & p.Thr42Ala \\
\hline \multirow[t]{14}{*}{ Exon 3} & 38 & c. $172 \mathrm{~A}>\mathrm{G}$ & 3 & p.Asn58Asp \\
\hline & & c. 174 C > G & 1 & p.Asn58Lys \\
\hline & & c. $179 \mathrm{G}>\mathrm{C}$ & 4 & p.Gly60Ala \\
\hline & & c. $181 \mathrm{G}>\mathrm{A}$ & 4 & p.Asp61Asn \\
\hline & & c. $188 A>G$ & 3 & p.Try63Cys \\
\hline & & C.182 A > G & 7 & p.Asp61Gly \\
\hline & & c. $184 \mathrm{~T}>\mathrm{G}$ & 1 & p.Tyr62Asp \\
\hline & & $c .205 \mathrm{G}>C$ & 1 & p.Glu69Gln \\
\hline & & C. $211 \mathrm{~T}>\mathrm{C}$ & 1 & p.Phe71Lue \\
\hline & & $c .214 G>T$ & 2 & p.Ala72Ser \\
\hline & & $c .215 C>G$ & 2 & p.Ala72Gly \\
\hline & & $c .218 C>T$ & 2 & p.Thr73lle \\
\hline & & $c .236 A>G$ & 6 & p.Gln79Arg \\
\hline & & C.317 A > C & 1 & p.Asp106Ala \\
\hline \multirow[t]{2}{*}{ Exon4 } & 4 & $c .417 \mathrm{G}>\mathrm{C}$ & 3 & p.Glu139Asp \\
\hline & & $c .455 G>A$ & 1 & p.Arg152His \\
\hline \multirow[t]{3}{*}{ Exon7 } & 7 & c. $767 \mathrm{~A}>\mathrm{G}$ & 2 & p.GIn256Arg \\
\hline & & c. $802 \mathrm{G}>\mathrm{A}$ & 1 & p.Gly268Ser \\
\hline & & C. $836 \mathrm{~A}>\mathrm{G}$ & 4 & p.Tyr279Cys \\
\hline \multirow[t]{4}{*}{ Exon8 } & 28 & $\mathrm{c} .854 \mathrm{~T}>\mathrm{C}$ & 4 & p.Phe285Ser \\
\hline & & $c .922 A>G^{b}$ & 12 & p.Asn308Asp \\
\hline & & c. $923 \mathrm{~A}>\mathrm{G}^{\mathrm{b}}$ & 10 & p.Asn308Ser \\
\hline & & $\mathrm{c} .855 \mathrm{~T}>\mathrm{G}$ & 2 & p.Phe285Leu \\
\hline Exon 9 & 2 & c. $1052 \mathrm{G}>\mathrm{A}$ & 2 & p.Arg351Gln \\
\hline Exon 12 & 6 & c. $1403 C>T$ & 6 & p.Thr468Met \\
\hline \multirow[t]{6}{*}{ Exon 13} & 19 & c. $1504 \mathrm{~T}>\mathrm{A}$ & 5 & p.Ser502Thr \\
\hline & & c.1505 C> T & 3 & p.Ser502Leu \\
\hline & & c. $1507 \mathrm{G}>\mathrm{A}$ & 3 & p.Gly503Arg \\
\hline & & c. $1510 A>G$ & 5 & p.Met504Val \\
\hline & & C.1517 A >C & 1 & p.GIn506Pro \\
\hline & & c. 1528 C > G & 2 & p.Gln510Glu \\
\hline
\end{tabular}

${ }^{a}$ In the current study 32 different PTPN11 pathogenic variations were observed

${ }^{\mathrm{b}}$ The 2 most common variations observed affecting the same amino acid residue

p.Asn308Ser, which results from a mutation in the same codon (c.923A $>$ G), is included (Table 2). This is consistent with findings from other studies [11, 24, 30]. Eighteen (18) parent sets of the positive cases were screened for the pathogenic variant found in the proband and in 10 families one parent was positive for the pathogenic variant that was seen in the proband (Fig. 3).

A large phenotypic variability is observed among NS patients with the same pathogenic variant, indicating variable expressivity and penetrance [56, 57]. Sixtyseven of the patients with pathogenic variants in
PTPN11 had congenital heart defects (84\%), with pulmonary stenosis and secundum type atrial septal defect each accounting for $35.3 \%$ of the cardiac anomalies. Hypertrophic cardiomyopathy (HCM) was seen in $8.5 \%$ and ventricular septum defect (VSD) in $4.8 \%$ of the patients. Congenital heart defects (CHD) were seen most frequently in patients with pathogenic variants in exon 3 ( 28 out of 38 patients) and exon 8 (18out of 28 patients) of the PTPN11 gene see (Additional file 2). 21(19.06\%) patients out of 107 patients with PTPN11 pathogenic variants did not have cardiac issues or had not undergone any cardiac evaluations. 


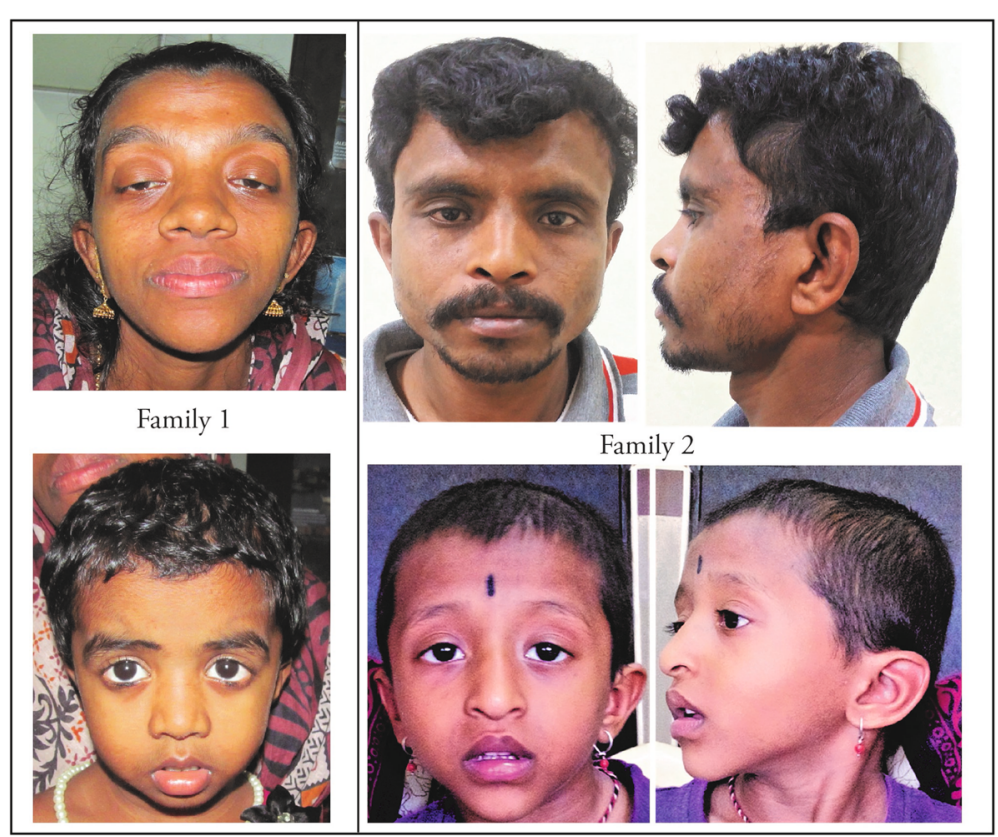

Fig. 3 Facial features observed in two NS families. Family 1-Mother and daughter with the pathogenic variant c.923A>G in exon 8 of the PTPN11 gene. Family 2- Father and son with the c.922A > G pathogenic variant in exon 8 of the PTPN11 gene

The other features observed with high frequency in the patients with PTPN11 pathogenic variants were downward slanting palpebral fissures (84\%), low-set posteriorly rotated ears (67\%) and webbed neck (61\%). Sternal deformities (pectus excavatum and pectus carinatum) were seen in $54 \%$ and in combination with pulmonary stenosis was observed in $30 \%$ of the pathogenic variant-positive patients. $44 \%$ of male patients with PTPN11 variants were observed to have unilateral or bilateral cryptorchidism. All patients with PTPN11 pathogenic variants had near-normal developmental milestones and cognitive abilities and the majority attended mainstream school. Short stature (height $<3$ rd centile for age) was noted in only $40 \%$ of mutation positive patients.

\section{Discussion}

\section{PTPN11 pathogenic variants}

There are now numerous studies that have screened for and reported PTPN11 pathogenic variants in NS patients. Mutation detection rates have varied from 22 to $100 \%$ (Table 3). The table shows that there have been other studies that found a low percentage of patients with PTPN11 pathogenic variants like the present study (29\%) $[15,16,19,21-23,27,28]$. This substantiates the fact that NS is a genetically heterogeneous syndrome, and may imply higher frequency of pathogenic variants among the other 13 genes known to cause NS and possibly in other, yet unidentified genes. The large-cohort study published by Ezquieta et al [27] in 2012 had 643 patients of whom 172 (27\%) had pathogenic variants in PTPN11. Zenker et al. [11] recruited patients from the paediatric cardiology department and showed a $60 \%$ detection of pathogenic variants, suggesting that the method of patient recruitment may change pathogenic variant detection rates.

All the pathogenic variants identified in our cohort are previously reported missense changes and occur at positions that are conserved among vertebrate PTPN11 orthologous genes. A majority of these are in exons 3 and 8 , as reported in earlier studies, and account for $62 \%$ of the PTPN11 pathogenic variants (Fig. 1). In the present study 91 of the 107 patients $(85 \%)$ with pathogenic variants have the variants in exons 3, 8, 12 and 13; this proportion is consistent over most studies [11, 13 , $19,21,30$ ]. The change c.922A $>\mathrm{G}$, which results in p.Asn308Asp, was the most common pathogenic variant we observed. This is consistent with most of the other PTPN11 mutation studies and therefore position 922 in PTPN11 can be regarded as a mutation hotspot. The amino acid residue 308 lies in the PTP domain of the protein (which contains four loops, P loop, pY loop, WPD loop and Q loop) and is not involved in direct interactions with the N-SH2 domain [58]. The Asp at this position forms extra hydrogen bonds with $\mathrm{pY}$ loop residues making the $\mathrm{pY}$ and the $\mathrm{P}$ loops less flexible and renders the enzyme better configured for catalysis by maintaining the open conformation. The extent of rigidity or flexibility between the $\mathrm{pY}$ and $\mathrm{P}$ loops determines the ability of the N-SH2 domain to close back upon the 
Table 3 Comparison of PTPN11 pathogenic variant data and their association with heart defects in our study and in other NS

\begin{tabular}{|c|c|c|c|c|c|}
\hline Study & No. of patients tested & $\begin{array}{l}\text { No. of PTPN11 } \\
\text { positive patients (\%) }\end{array}$ & $\begin{array}{l}\text { Percentage of } \\
\text { PTPN11 positive } \\
\text { patients with PS }\end{array}$ & $\begin{array}{l}\text { Percentage of PTPN11 } \\
\text { Positive patients with } \\
\text { (Septal defects) ASD + VSD }\end{array}$ & $\begin{array}{l}\text { Percentage of } \\
\text { PTPN11 positive } \\
\text { patients with HCM }\end{array}$ \\
\hline Atik et al. 2015 [10] & 20 & $20(100)$ & 55 & 5 & 10 \\
\hline Bertola et al. 2006 [26] & 61 & $26(42.6)$ & 67 & - & 10 \\
\hline Cizmarova et al. 2016 [14] & 51 & $22(43)$ & 63 & 31.79 & 9.09 \\
\hline Dallapicola et al. 2003 [13] & 84 & $34(40)$ & 41 & 5.90 & 23.05 \\
\hline Ezquieta et al. 2012 [27] & 643 & $172(27)$ & 49 & - & 3.48 \\
\hline Ferrero et al 2008 [28] & 40 & $14(31.5)$ & 85.70 & 7.14 & 7.14 \\
\hline Hung et al. 2007 [29] & 34 & 13(38) & - & - & - \\
\hline Jongmans et al. 2005 [30] & 170 & $76(45)$ & 68 & 30 & 7 \\
\hline Kiper et al. 2012 [15] & 31 & $9(28)$ & 55 & 33 & 11.10 \\
\hline Kosaki et al. 2002 [16] & 21 & $7(33)$ & 42 & 42 & - \\
\hline Louati et al 2014 [17] & 19 & $9(43)$ & 88 & 22.20 & - \\
\hline Maheshwari et al. 2002 [18] & 16 & $8(50)$ & 75 & 18.75 & - \\
\hline Min Ko et al. 2008 [19] & 59 & $16(27)$ & 50 & 36 & 18 \\
\hline Mona L. Essawi et al. 2013 [20] & 21 & $21(100)$ & 24 & - & 19 \\
\hline Musante et al. 2002 [21] & 96 & $32(33)$ & 70 & 23 & - \\
\hline Papadopoulous et al. 2011 [22] & 60 & $17(29)$ & 65 & 17 & - \\
\hline Rodriguez et al 2014 [23] & 18 & $4(22)$ & 25 & - & - \\
\hline Shuba Phadke et al. 2017 [1] & 17 & $11(64.7)$ & 54 & 36.36 & - \\
\hline Tartaglia et al. 2002 [24] & 119 & $54(45)$ & 70 & 12 & 5.90 \\
\hline Yoshida et al. 2004 [25] & 45 & $18(40)$ & 88 & 88 & - \\
\hline Zenker et.al 2004 [11] & 57 & $34(60)$ & 88 & 94 & 26.40 \\
\hline Current study & 363 & $107(29)$ & 35.3 & 40.01 & 8.5 \\
\hline
\end{tabular}

PS Pulmonary stenosis, ASD - Atrial septal defect; VSD - Ventricular septal defect; HCM - Hypertrophic cardiomyopathy

PTP domain once it is in the open configuration. Keilhack et al [59] showed that the Asn308Asp change caused the enzyme to have increased basal as well as stimulated activity compared to the wild-type enzyme. This feature of the SHP2 protein, where the open or unlocked state allows the catalytic function, explains the gain-of-function mechanism of most of the mutations seen in PTPN11 that cause locking up of the enzyme in the open state. This is due to various interactions that are gained or lost owing to the amino acid change. In another mechanism for locking the enzyme in the open configuration, the Asp61Gly mutation in the N-SH2 domain weakens its interaction with the PTP domain, leaving the enzyme in the active catalytic state [60].

The absence of frameshift, nonsense or even splicing mutations in our cohort and in other similar studies implies that there is no haploinsufficiency in PTPN11 expression and that PTPN11 haploinsufficiency does not cause NS. Lee et al [61] and Yoshida et al [25] reported frameshift mutations that cause the changes Asp61del and Gly60del and showed that the changes resulted in an opening of the catalytic site, therefore functioning via positive upregulation as opposed to haploinsufficiency of the wild-type gene. Three splicing mutations reported earlier by Bowen et al [62] are associated with metachondrochromatosis, which is a result of loss-offunction mutations. This study identified five frameshift, two nonsense, three splice-site, and one large-deletion mutations in 11 families, with each family harbouring a different mutation and the mutations identified were spread throughout the gene.

\section{Genotype-phenotype correlation}

Nearly all studies carried out to date on NS mutation testing have attempted genotype-phenotype correlation. However, the most consistent feature across studies has been that there exists a great deal of phenotypic variation even among patients with the same pathogenic variant [56]. Several PTPN11 functional studies have addressed different developmental aspects and shed some light on the probable causes of such variation based on SHP2 functionality $[49,52,63]$.

Among mutation-positive patients $40 \%$ exhibited short stature (height $<3$ rd centile for age). This may be because 
the majority of patients were young children seen before pubertal growth had been completed [64].

Characterization of facial features can vary as this is still based on subjective assessment [17]. The most commonly observed facial features in our study were downward slanting palpebral fissures followed by lowset posteriorly rotated ears. A recent study by Kruszka et al (2017) [65] used facial analysis technology to assess facial deformities associated with NS. This may prove to be the way forward to overcome subjective assessment bias.

Eight patients in our cohort had café au lait spots / multiple lentigines; three of them had pathogenic variants in exon 3 (c.182A > G, c.188A > G and c.236A > G), two patients in exon 4 (c.417G $>\mathrm{C}$ ), two in exon 7 (c.767A $>\mathrm{G}$ and c.836A $>\mathrm{G}$ ), and one patient with a pathogenic variant in exon 13 (c.1504 T >A). Earlier reports of NS patients with café au lait spots / multiple lentigines did not report pathogenic variants in exon 3 or exon 4. Of the six patients with c.1403C $>\mathrm{T}$ (p.Thr468Met) known to be associated with Noonan like syndrome with multiple lentigens, only one showed presence of multiple lentigines but three others had thick curly or woolly hair. As lentigines increase with age and the majority of our patients were younger than 5 years, the frequency of patients with lentigines in our study may be lower than that in other studies. Thirteen patients with mutations in exons 7,12 and 13, some of which are associated with LEOPARD syndrome were identified. Of these, only two patients (with mutations in exons 7 and 12) had the classic features, including deafness, cardiac rhythm abnormalities and widespread multiple lentigines. There was also a high correlation of patients with pectus deformity with pathogenic variants in exon 13 (10 out of 19 patients) see (Additional file 2).

Our cohort had CHD (in 84\% of patients with pathogenic variants) mainly consisting of right-sided cardiac anomalies [57]. Studies by Zenker [11], Tartaglia [66], Louati [17] and Ferrero [28] also reported high frequency of $\mathrm{CHD}$. The most frequently occurring pathogenic variants in our cohort, c.922A > G and c.923A > G, both of which change the same amino acid (Asn308), were seen in 22 patients, including a three-generationaffected pedigree.

We did not detect any pathogenic variants in the $\mathrm{C}$ terminal region, which is consistent with most other studies [17].

Of the 18 sets of parents screened in our study for the causal pathogenic variant, seven fathers and three mothers carried the variant detected in the child. Three of these children had cardiac defects (two PS and one ASD) that were not present in the parents. This may be explained by intrafamilial variability with milder phenotypes in reproductively fit parents or may be as a result of cardiac involvement in parents regressing or improving with age.

\section{Conclusion}

Although next-generation sequencing (NGS) using a RASopathy gene panel is the way forward for NS and other RASopathy testing, the cost involved might be an inhibiting factor for patients from low economic backgrounds and countries where such testing is expensive and/or not routinely available. In such settings we propose a preliminary protocol based on our findings and other similar studies. This involves sequencing of PTPN11 exons 3 and 8 followed by 13, especially if the clinical features include heart defects, downward slanting palpebral fissures, webbed neck, low-set posteriorly rotated ears and pectus abnormalities.

No single clinical feature was seen consistently across all patients, confirming the wide variability observed among NS patients. Most of the clinical findings reported in our cohort are in keeping with those in other large studies reported in the literature [67-69].

To our knowledge, this report is the largest series of PTPN11 variant-positive cases reported in Asian Indian individuals. The 256 patients who were found to be PTPN11 variant-negative are the subject of an NGS panel study involving 22 other genes implicated in causation of NS and other RASopathies.

\section{Supplementary information}

Supplementary information accompanies this paper at https://doi.org/10. 1186/s12881-020-0986-5.

Additional file 1. Primers for exon sequencing.

Additional file 2. Exon-wise comparison of the clinical features.

\section{Abbreviations}

CHD: Congenital heart defects; NS: Noonan syndrome; NT: Nuchal translucency; PLI: Pragmatic language impairment; PTPN11: Protein tyrosine phosphate non-receptor type11

\section{Acknowledgements}

Not applicable.

\section{Authors' contributions}

SS, MB and JPA drafted the manuscript; MB, SN, KG and SGN clinically diagnosed, assesed and provided patient samples with their clinical details for the study; JPA, VP and MOF performed the genomic DNA extraction, molecular-genetic testing and data analysis; JPA acquired the clinical data and performed computation, analysis, tabulation and collation of the data with interpretation. SS is the Principal Investigator of this study, she designed, collated, analysed data and supervised the study. All the authors have reviewed and approved the final manuscript.

\section{Funding}

The study was partially supported by the Indian Council of Medical Research [ICMR]. ICMR had no direct role to play in study design, sample collection, data interpretation or in manuscript preparation. The study was also supported by the Centre for Human Genetics, Bengaluru, India. 


\section{Availability of data and materials}

All sanger sequencing data generated and analysed in the current study are available on the Genbank database. Accession numbers are MT052193MT052299.

\section{Ethics approval and consent to participate}

All the tests performed in the current study involving human participants were reviewed and approved by the Institutional Ethics Committee of Centre for Human Genetics, Bengaluru and in agreement with their ethical standards.

According to Indian Council for Medical Research (ICMR) bioethical guidelines (2017), verbal consent (assent) to participate for paediatric patients aged between 7 and 12 years is deemed acceptable. The Institutional Ethics Committee of Centre for Human Genetics, Bengaluru was in agreement with this guideline and written and verbal consent to participate was obtained from the parents or legal guardians for all patients under the age of 16 . Written consent to participate was obtained for all patients aged 16 and over

\section{Consent for publication}

A written informed consent for publication of medical data and/or clinical images was obtained from the parents or legal guardians for all paediatric patients under the age of 18 . For patients above 18 years of age assent and written consent has been obtained for publication of medical data and /or clinical images.

\section{Competing interests}

The authors declare that they have no competing interests.

\section{Author details}

${ }^{1}$ Molecular Genetics, Centre for Human Genetics, Bengaluru 560100, India. ${ }^{2}$ Pediatric Genetics, Indira Gandhi Institute of Child Health, Bengaluru 560029, India. ${ }^{3}$ Pediatric Genetics, Amrita Institute of Medical Sciences \& Research Centre (AIMS), Kochi 682041, India. ${ }^{4}$ Medical Genetics, Kanchi Kamakoti CHILDS Trust Hospital, Chennai 600034, India.

Received: 18 September 2019 Accepted: 25 February 2020 Published online: 12 March 2020

\section{References}

1. Narayanan DL, Pandey H, Moirangthem A, et al. Indian Pediatr. 2017;54:638. https://doi.org/10.1007/s13312-017-1125-z..

2. Tartaglia M, Gelb BD, Zenker M. Noonan syndrome and clinically related disorders. Best Pract Res Clin Endocrinol Metab. 2011;25:161-79. https://doi. org/10.1016/j.beem.2010.09.002.

3. Tidyman WE, Rauen KA. Expansion of the RASopathies. Curr Genet Med Rep. 2016;4:57-64.

4. Cesur Aydin K, Ozcan I, Bona G. Noonan syndrome: A review. Minerva Pediatr. 2008;60:343-6.

5. Allanson JE. Noonan syndrome. Am J Med Genet Part C Semin Med Genet. 2007;145C:274-9.

6. Noonan JA. Hypertelorism with turner phenotype: a new syndrome with associated congenital heart disease. Am J Dis Child. 1968;116(4):373-80. https://doi.org/10.1001/archpedi.1968.02100020377005.

7. Pierpont MEM, Digilio MC. Cardiovascular disease in Noonan syndrome. Curr Opin Pediatr. 2018;30(5):601-8. https://doi.org/10.1097/MOP. 000000000000066

8. Chen H, Li X, Liu X, Wang J, Zhang Z, Wu J, et al. Clinical and mutation profile of pediatric patients with RASopathy-associated hypertrophic cardiomyopathy: results from a Chinese cohort. Orphanet J Rare Dis. 2019; 14:1-8.

9. Allanson JE. Objective studies of the face of Noonan, Cardio-faciocutaneous, and Costello syndromes: A comparison of three disorders of the Ras/MAPK signaling pathway. Am J Med Genet Part A. 2016;170A(10):25707.

10. Atik T, Aykut A, Hazan F, Onay H, Goksen D, Darcan S, et al. Mutation Spectrum and phenotypic features in Noonan syndrome with PTPN11 mutations: definition of two novel mutations. Indian J Pediatr. 2016;83:51721.

11. Zenker M, Buheitel G, Rauch R, Koenig R, Bosse K, Kress W, et al. Genotypephenotype correlations in Noonan syndrome clinical evaluation subjects were recruited from two departments of pediatric cardiology $(n=33)$, two departments of pediatric endocrinology $(n=4)$, and three clinical. J Pediatr. 2004;144(3):368-74.

12. Brasil AS, Pereira AC, Wanderley LT, Kim CA, Malaquias AC, Jorge AAL, et al. PTPN11 and KRAS gene analysis in patients with Noonan and Noonan-like syndromes. Genet Test Mol Biomarkers. 2010;14:425-32. https://doi.org/10. 1089/gtmb.2009.0192.

13. Sarkozy A, Marino B, Pizzuti A, Dallapiccola B. Correlation between PTPN11 gene mutations and congenital heart defects in Noonan and LEOPARD syndromes. J Med Genet. 2003;40(9):704-8.

14. Čizmárová M, Hlinková K, Bertok S, Kotnik P, Duba HC, Bertalan R, et al. New mutations associated with Rasopathies in a central European population and genotype-phenotype correlations. Ann Hum Genet. 2016;80:50-62.

15. Şimşek-Kiper P, Alanay Y, Gülhan B, Lissewski C, Türkyilmaz D, Alehan D, et al. Clinical and molecular analysis of RASopathies in a group of Turkish patients. Clin Genet. 2013;83:181-6.

16. Kosaki K, Suzuki T, Muroya K, Hasegawa T, Sato S, Matsuo N, et al. PTPN11 (protein-tyrosine phosphatase, nonreceptor-type 11) mutations in seven Japanese patients with Noonan syndrome. J Clin Endocrinol Metab. 2002;87: 3529-33.

17. Louati R, Abdelmoula NB, Trabelsi I, Abid D, Lissewski C, Kharrat N, et al. Clinical and molecular findings of tunisian patients with rasopathies. Mol Syndromol. 2014;5:212-7.

18. Maheshwari M, Belmont J, Fernbach S, Ho T, Molinari L, Yakub I, et al. PTPN11 mutations in Noonan syndrome type I: detection of recurrent mutations in exons 3 and 13. Hum Mutat. 2002;20:298-304.

19. Ko JM, Kim JM, Kim GH, Yoo HW. PTPN11, SOS1, KRAS, and RAF1 gene analysis, and genotype-phenotype correlation in Korean patients with Noonan syndrome. J Hum Genet. 2008:53:999-1006.

20. Essawi ML, Ismail MF, Afifi HH, Kobesiy MM, El Kotoury A, Barakat MM. Mutational analysis of the PTPN11 gene in Egyptian patients with Noonan syndrome. J Formos Med Assoc. 2013;112:707-12. https://doi.org/10.1016/j. jfma.2012.06.002.

21. Musante L, Kehl HG, Majewski F, Meinecke P, Schweiger S, Gillessen-Kaesbach $\mathrm{G}$, et al. Spectrum of mutations in PTPN11 and genotype - phenotype correlation in 96 patients with Noonan syndrome and five patients with cardio-facio-cutaneous syndrome. Eur J Hum Genet. 2003;11:201-6.

22. Papadopoulou A, Issakidis M, Gole E, Kosma K, Fryssira H, Fretzayas A, et al. Phenotypic spectrum of 80 Greek patients referred as Noonan syndrome and PTPN11 mutation analysis: the value of initial clinical assessment. Eur J Pediatr. 2012;171:51-8.

23. Rodríguez FA, Unanue N, Hernández Ml, Heath KE, Cassorla F. Molecular characterization of Chilean patients with a clinical diagnosis of Noonan syndrome. J Pediatr Endocrinol Metab. 2014;27:305-9.

24. Tartaglia M, Kamini K, Adam S, Xiaoling S, Musat DL, van der Burgt I, Brunner HG, Bertola DR, Crosby A, et al. PTPN11 Mutations in Noonan Syndrome: Molecular Spectrum,Genotype-Phenotype Correlation, and Phenotypic Heterogeneity. Am J Hum Genet. 2002;70(6):1555-63. https:// doi.org/10.1086/340847.

25. Yoshida R, Hasegawa T, Hasegawa Y, Nagai T, Kinoshita E, Tanaka Y, et al. Protein-tyrosine phosphatase, nonreceptor type 11 mutation analysis and clinical assessment in 45 patients with Noonan syndrome. J Clin Endocrinol Metab. 2004:89:3359-64.

26. Bertola DR, Pereira AC, Maria L, Albano J, Oliveira PSLDE, Kim CA, et al. PTPN11 gene analysis in 74 Brazilian patients with Noonan. Genet Test. 2006;10(3):186-91.

27. Ezquieta B, Santomé $J$, Carcavilla A, Guillén-Navarro E, Pérez-Aytés A, Sánchez del Pozo J, et al. Alterations in RAS-MAPK Genes in 200 Spanish Patients With Noonan and Other Neuro-Cardio-Facio-Cutaneous Syndromes. Genotype and Cardiopathy. Rev Esp Cardiol (Engl Ed). 2012;65:447-55. https://doi.org/10.1016/j.rec.2011.12.017.

28. Ferrero $G B$, Baldassarre $G$, Delmonaco AG, Biamino E, Banaudi E, Carta C, et al. Clinical and molecular characterization of 40 patients with Noonan syndrome. Eur J Med Genet. 2008;51:566-72. https://doi.org/10.1016/j.ejmg. 2008.06.011

29. Hung CS, Lin JL, Lee YJ, Lin SP, Chao MC, Lo FS. Mutational analysis of PTPN11 gene in Taiwanese children with Noonan syndrome. J Formos Med Assoc. 2007;106:169-72. https://doi.org/10.1016/S0929-6646(09)60235-7.

30. Jongmans $M$, Sistermans EA, Rikken A, Nillesen WM, Tamminga R, Patton $M$, et al. Genotypic and phenotypic characterization of Noonan syndrome: new data and review of the literature. Am J Med Genet. 2005;134(A):165-70. 
31. Copel J, Sinkey RG, Odibo AO. Noonan Syndrome. Obstet Imaging Fetal Diagnosis Care Second Ed. 2017;6:564-7 e1.

32. Pannone L, Bocchinfuso G, Flex E, Rossi C, Magliozzi M, Anselmi M, et al. Structural, functional and clinical characterization of a novel PTPN11 mutation cluster underlying Noonan syndrome. Hum Mutat. 2017;38(4):451-9.

33. Selås $\mathrm{M}$, Helland WA. Pragmatic language impairment in children with Noonan syndrome. Clin Linguist Phonetics. 2016;30:899-910. https://doi.org/ 10.1080/02699206.2016.1188422.

34. Croonen EA, Nillesen WM, Stuurman KE, Oudesluijs G, Van De Laar IMBM, Martens $L$, et al. Prenatal diagnostic testing of the Noonan syndrome genes in fetuses with abnormal ultrasound findings. Eur J Hum Genet. 2013;21: 936-42. https://doi.org/10.1038/ejhg.2012.285.

35. Niihori T, Aoki Y, Narumi $Y$, Neri G, Cavé $H$, Verloes A, et al. Germline KRAS and BRAF mutations in cardio-facio-cutaneous syndrome. Nat Genet. 2006 38:294-6.

36. Roberts AE, Araki T, Swanson KD, Montgomery KT, Schiripo TA, Joshi VA, et al. Germline gain-of-function mutations in SOS1 cause Noonan syndrome. Nat Genet. 2007;39:70-4.

37. Martinelli S, De Luca A, Stellacci E, Rossi C, Checquolo S, Lepri F, et al. Heterozygous germline mutations in the CBL tumor-suppressor gene cause a Noonan syndrome-like phenotype. Am J Hum Genet. 2010;87:250-7. https://doi.org/10.1016/j.ajhg.2010.06.015.

38. Brems H, Chmara M, Sahbatou M, Denayer E, Taniguchi K, Kato R, et al. Germline loss-of-function mutations in SPRED1 cause a neurofibromatosis 1like phenotype. Nat Genet. 2007;39:1120-6.

39. Aoki Y, Niihori T, Kawame H, Kurosawa K, Ohashi H, Tanaka Y, et al. Germline mutations in HRAS proto-oncogene cause Costello syndrome. Nat Genet. 2005:37:1038-40.

40. Razzaque MA, Nishizawa T, Komoike $Y$, Yagi H, Furutani M, Amo R, et al. Germline gain-of-function mutations in RAF1 cause Noonan syndrome. Nat Genet. 2007;39:1013-7.

41. Pandit B, Sarkozy A, Pennacchio LA, Carta C, Oishi K, Martinelli S, et al. Gainof-function RAF1 mutations cause Noonan and LEOPARD syndromes with hypertrophic cardiomyopathy. Nat Genet. 2007;39:1007-12.

42. Wallace MR, Marchuk DA, Andersen LB, Letcher R, Odeh HM, Saulino AM, et al. Type 1 neurofibromatosis gene: Identification of a large transcript disrupted in three NF1 patients. Science. 1990;249:181-6.

43. Riccardi VM. J Nueropathol Exp Nuerol. 1992;51(6):658.

44. Schubbert S, Zenker M, Rowe SL, Böll S, Klein C, Bollag G, et al. Germline KRAS mutations cause Noonan syndrome. Nat Genet. 2006;38:331-6.

45. Cirstea IC, Kutsche K, Dvorsky R, Gremer L, Carta C, Horn D, et al. A restricted spectrum of NRAS mutations causes Noonan syndrome. Nat Genet. 2010;42: 27-9. https://doi.org/10.1038/ng.497.

46. Cordeddu V, Di Schiavi E, Pennacchio LA, Ma'ayan A, Sarkozy A, Fodale V, et al. Mutation of SHOC2 promotes aberrant protein $\mathrm{N}$-myristoylation and causes Noonan-like syndrome with loose anagen hair. Nat Genet. 2009;41: $1022-6$

47. Niemeyer CM, Kang MW, Shin DH, Furlan I, Erlacher M, Bunin NJ, et al. Germline CBL mutations cause developmental abnormalities and predispose to juvenile myelomonocytic leukemia. Nat Genet. 2010;42:641. https://doi.org/10.1038/ng.641.

48. Gripp KW, Aldinger KA, Bennett JT, Baker L, Tusi J, Powell-Hamilton N, et al. A novel rasopathy caused by recurrent de novo missense mutations in PPP1CB closely resembles Noonan syndrome with loose anagen hair. Am J Med Genet Part A. 2016;170:2237-47.

49. Tajan M, de Rocca SA, Valet P, Edouard T, Yart A. SHP2 sails from physiology to pathology. Eur J Med Genet. 2015;58:509-25.

50. Pawson T, Saxton TM. Signaling networks - do all roads Lead to the same genes ? Cell. 1999;97(6):675-8.

51. Neel BG, Gu H, Pao L. The 'Shp'ing news: SH2 domain-containing tyrosine phosphatases in cell signaling. Trends Biochem Sci. 2003;28:284-93.

52. De Rocca A, Edouard T, Karine T, Dance M, Yart A, Salles J-P, Tajan M, Valet P, Mus M, et al. Noonan syndrome-causing SHP2 mutants inhibit insulin-like growth factor 1 release via growth hormone-induced ERK hyperactivation, which contributes to short stature. Proc Natl Acad Sci. 2012;109:4257-62. https://doi.org/10.1073/pnas.1119803109.

53. Vitenskap MOG. Mutational diagnostics in syndromes linked to the RAS / MAPK signal path. J Nor Legeforen. 2009;22:129.

54. Cunnick JM, Meng S, Ren Y, Desponts C, Wang HG, Djeu JY, et al. Regulation of the mitogen-activated protein kinase signaling pathway by SHP2. J Biol Chem. 2002;277:9498-504.
55. Lapinski PE, Meyer MF, Feng G, Kamiya N, King PD. Deletion of SHP-2 in mesenchymal stem cells causes growth retardation, limb and chest deformity, and calvarial defects in mice. Dis Model Mech. 2013;6(6):1448-58.

56. Pierpont El, Pierpont ME, Mendelsohn NJ, Roberts AE, Tworog-Dube E Seidenberg MS. Genotype differences in cognitive functioning in Noonan syndrome. Genes Brain Behav. 2009;8:275-82.

57. Raaijmakers R, Noordam C, Noonan JA, et al. Are ECG abnormalities in Noonan syndrome characteristic for the syndrome? Eur J Pediatr. 2008;167: 1363.

58. Qiu W, Wang X, Romanov V, et al. Structural insights into Noonan/LEOPARD syndrome-related mutants of protein-tyrosine phosphatase SHP2 (PTPN11). BMC Struct Biol. 2014;14:10. https://doi.org/10.1186/1472-6807-14-10.

59. Keilhack H, David FS, McGregor M, Cantley LC, Neel BG. Diverse biochemical properties of Shp2 mutants: implications for disease phenotypes. J Biol Chem. 2005:280:30984-93.

60. Bentires-alj M, Paez JG, David FS, Keilhack H, Halmos B, Naoki K, et al. Activating mutations of the Noonan syndrome-associated SHP2 / PTPN11 gene in human solid tumors and adult acute Myelogenous leukemia. Cancer Res. 2004;64(24):8816-20.

61. Lee WH, Raas-Rotschild A, Miteva MA, Bolasco G, Rein A, Gillis D, et al. Noonan syndrome type I with PTPN11 3 bp deletion: structure-function implications. Proteins Struct Funct Genet. 2005:58:7-13.

62. Bowen M, Boyden E, Holm I, Campos-Xavier B, Bonafe L, Superti-Furga A, Ikegawa S, Cormier-Daire V, Bovee J, Pansuriya T, De Sousa S. Loss-ofFunction Mutations in PTPN11 Cause Metachondromatosis, but Not Ollier Disease or Maffucci Syndrome. PLoS Genetics. 2011;7(4). https://doi.org/10. 1371/journal.pgen.1002050

63. Araki T, Chan G, Newbigging S, Morikawa L, Bronson RT, Neel BG. Noonan syndrome cardiac defects are caused by PTPN11 acting in endocardium to enhance endocardial-mesenchymal transformation. Proc Natl Acad Sci. 2009;106:4736-41. https://doi.org/10.1073/pnas.0810053106.

64. Otten BJ, Noordam C. Growth in Noonan Syndrome. Horm Res. 2009; 72(Suppl 2):31-5. https://doi.org/10.1159/000243776.

65. Kruszka P, Porras AR, Addissie YA, Moresco A, Medrano S, Mok GTK, et al. Noonan syndrome in diverse populations. Am J Med Genet Part A. 2017; 173:2323-34.

66. Gelb BD, Roberts AE, Tartaglia M. Cardiomyopathies in Noonan syndrome and the other RASopathies. Prog Pediatr Cardiol. 2015;39:13-9. https://doi. org/10.1016/j.ppedcard.2015.01.002.

67. Marino B, Digilio MC, Toscano A, Giannotti A, Dallapiccola B. Congenital heart diseases in children with Noonan syndrome: an expanded cardiac spectrum with high prevalence of atrioventricular canal. J Pediatr. 1999;135: 703-6.

68. Bertola DR, Chong AK, Sugayama SMM, Albano LMJ, Wagenführ J, Moysés $\mathrm{RL}$, et al. Cardiac findings in 31 patients with Noonan's syndrome. Arq Bras Cardiol. 2005;75:409-12.

69. Bertola DR, Pereira AC, De Oliveira PSL, Kim CA, Krieger JE. Clinical variability in a Noonan syndrome family with a new PTPN11 gene mutation. Am J Med Genet. 2004;130(A):378-83.

\section{Publisher's Note}

Springer Nature remains neutral with regard to jurisdictional claims in published maps and institutional affiliations.

Ready to submit your research? Choose BMC and benefit from:

- fast, convenient online submission

- thorough peer review by experienced researchers in your field

- rapid publication on acceptance

- support for research data, including large and complex data types

- gold Open Access which fosters wider collaboration and increased citations

- maximum visibility for your research: over $100 \mathrm{M}$ website views per year

At $\mathrm{BMC}$, research is always in progress.

Learn more biomedcentral.com/submission 